Int. J. Electrochem. Sci., 13 (2018) 3297 - 3308

International Journal of

ELECTROCHEMICAL

SCIENCE

www.electrochemsci.org

Short Communication

\title{
Electrochemical behaviour of API 5L X52 Steel Samples Immersed in Sulphate Aqueous Solutions with Different pH
}

\author{
Perla Morales Gil ${ }^{1, *}$, Baptiste Julien ${ }^{2}$, Manuel Palomar-Pardavé, \\ María Guadalupe Montes de Oca-Yemha ${ }^{2}$, María Teresa Ramírez-Silva ${ }^{3}$, Mario Romero-Romo ${ }^{2, *}$ \\ ${ }^{1}$ Instituto Mexicano del Petróleo, Laboratorio de Caracterización de Materiales Sintéticos y Naturales, \\ Eje Central Lázaro Cárdenas 152, Mexico City, CP 07730, CDMX, MÉXICO \\ ${ }^{2}$ INSA - LYON - Domaine Scientifique de la Doua - 20, Rue Albert Einstein 69621 Villeurbanne \\ Cedex - France. \\ ${ }^{3}$ Universidad Autónoma Metropolitana-Azcapotzalco, Departamento de Materiales, Av. San Pablo \\ 180 Col. Reynosa-Tamaulipas, Mexico City, CP 02200, CDMX, MÉXICO. \\ ${ }^{4}$ Universidad Autónoma Metropolitana-Iztapalapa, Departamento de Química, Av. San Rafael Atlixco \\ \#186, Col. Vicentina, Mexico City, CP 09340, CDMX. MÉXICO. \\ *E-mail: moralesp@imp.mx (P.M.G) and mmrr@correo.azc.uam.mx (M.R.R.)
}

doi: $10.20964 / 2018.04 .08$

Received: 7 November 2017 / Accepted: 18 January 2018 / Published: 6 March 2018

Formation of anodic films was induced through application of potential pulses on the surface of API 5L X52 steel samples immersed in a $0.1 \mathrm{M} \mathrm{H}_{2} \mathrm{SO}_{4}$ aqueous solution with different $\mathrm{pH}$ set by adding $\mathrm{NaOH}$. The formation mechanism was studied using the step potential technique to produce $j$ - $t$ plots, and the morphology and composition of the resulting films was characterized through SEM and EDX, respectively, and their passivating capacity was also electrochemically evaluated. It is shown that the anodic film was formed, in all cases, by means of nucleation and growth phenomena and that it cannot passivate the corrosion process. Furthermore, the nature of the films formed was also validated from a thermodynamic analysis based on the predominance zones diagram.

Keywords: Steel; Anodic films; pH; Potentiostatic current transients

\section{FULL TEXT}

(C) 2018 The Authors. Published by ESG (www.electrochemsci.org). This article is an open access article distributed under the terms and conditions of the Creative Commons Attribution license (http://creativecommons.org/licenses/by/4.0/). 